Article

\title{
Proposed Mechanism for the Antitrypanosomal Activity of Quercetin and Myricetin Isolated from Hypericum afrum Lam.: Phytochemistry, In Vitro Testing and Modeling Studies
}

\author{
Farida Larit ${ }^{1,2, *} \mathbb{0}$, Khaled M. Elokely ${ }^{3,4}{ }^{(}$, Manal A. Nael ${ }^{3,4}$, Samira Benyahia ${ }^{5}$, Francisco León ${ }^{2,6} \mathbb{D}^{\text {, }}$ \\ Stephen J. Cutler ${ }^{2,6}$ and Mohammed M. Ghoneim ${ }^{7,8, *}$ \\ 1 Département de Chimie, Faculté des Sciences Exactes, Université des Frères Mentouri Constantine 1, \\ Constantine 25000, Algeria \\ 2 Department of BioMolecular Sciences, Division of Medicinal Chemistry, University of Mississippi, University, \\ MS 38677, USA; jleon@mailbox.sc.edu (F.L.); sjcutler@cop.sc.edu (S.J.C.) \\ 3 Department of Chemistry, Institute for Computational Molecular Science, Temple University, \\ Philadelphia, PA 19122, USA; kelokely@temple.edu (K.M.E.); mnael@pharm.tanta.edu.eg (M.A.N.) \\ 4 Department of Pharmaceutical Chemistry, Faculty of Pharmacy, Tanta University, Tanta 31527, Egypt \\ 5 Laboratoire de Synthèse Organique, Modélisation et Optimisation des Procèdes (LOMOP), Université Badji \\ Mokhtar, Annaba 23000, Algeria; samira.benyahia13@gmail.com \\ 6 Department of Drug Discovery and Biomedical Sciences, College of Pharmacy, University of South Carolina, \\ Columbia, SC 29208, USA \\ 7 Department of Pharmacy Practice, College of Pharmacy, AlMaarefa University, Ad Diriyah, \\ Riyadh 13713, Saudi Arabia \\ check for \\ updates \\ Citation: Larit, F.; Elokely, K.M.; \\ 8 Department of Pharmacognosy, Faculty of Pharmacy, Al-Azhar University, Cairo 11371, Egypt \\ * Correspondence: laritfarida@umc.edu.dz (F.L.); mghoneim@mcst.edu.sa (M.M.G.); \\ Tel.: +966-537415011 (F.L. \& M.M.G.)
} Nael, M.A.; Benyahia, S.; León, F.; Cutler, S.J.; Ghoneim, M.M. Proposed Mechanism for the Antitrypanosomal Activity of Quercetin and Myricetin Isolated from Hypericum afrum Lam.: Phytochemistry, In Vitro Testing and Modeling Studies. Molecules 2021, 26, 1009. https://doi.org/10.3390/ molecules26041009

Academic Editor: Steve Peigneur

Received: 14 January 2021

Accepted: 10 February 2021

Published: 14 February 2021

Publisher's Note: MDPI stays neutral with regard to jurisdictional claims in published maps and institutional affiliations.

Copyright: (c) 2021 by the authors. Licensee MDPI, Basel, Switzerland. This article is an open access article distributed under the terms and conditions of the Creative Commons Attribution (CC BY) license (https:// creativecommons.org/licenses/by/ $4.0 /)$.
Abstract: The in vitro activity of $L$. donovani (promastigotes, axenic amastigotes and intracellular amastigotes in THP1 cells) and T. brucei, from the fractions obtained from the hydroalcoholic extract of the aerial part of Hypericum afrum and the isolated compounds, has been evaluated. The chloroform, ethyl acetate and $n$-butanol extracts showed significant antitrypanosomal activity towards $T$. brucei, with $\mathrm{IC}_{50}$ values of $12.35,13.53$ and $12.93 \mu \mathrm{g} / \mathrm{mL}$ and with $\mathrm{IC}_{90}$ values of 14.94, 19.31 and $18.67 \mu \mathrm{g} / \mathrm{mL}$, respectively. The phytochemical investigation of the fractions led to the isolation and identification of quercetin (1), myricitrin (2), biapigenin (3), myricetin (4), hyperoside (5), myricetin-3-O- $\beta$-D-galactopyranoside (6) and myricetin-3'-O- $\beta$-D-glucopyranoside (7). Myricetin$3^{\prime}$-O- $\beta$-D-glucopyranoside (7) has been isolated for the first time from this genus. The chemical structures were elucidated by using comprehensive one- and two-dimensional nuclear magnetic resonance (1D and 2D NMR) spectroscopic data, as well as high-resolution electrospray ionization mass spectrometry (HR-ESI-MS). These compounds have also been evaluated for their antiprotozoal activity. Quercetin (1) and myricetin (4) showed noteworthy activity against T. brucei, with $\mathrm{IC}_{50}$ and $\mathrm{IC}_{90}$ values of 7.52 and $5.71 \mu \mathrm{M}$, and 9.76 and $7.97 \mu \mathrm{M}$, respectively. The T. brucei hexokinase (TbHK1) enzyme was further explored as a potential target of quercetin and myricetin, using molecular modeling studies. This proposed mechanism assists in the exploration of new candidates for novel antitrypanosomal drugs.

Keywords: antitrypanosomal; antileishmanial; hexokinase (TbHK1); docking; flavonoids; Hypericum afrum

\section{Introduction}

Trypanosoma and Leishmania parasites are the etiological agents for the Trypanosomiasis and leishmaniasis diseases that affect millions of people worldwide [1]. The sand-fly is the vector for Leishmania donovani, which is the etiological agent of visceral leishmaniasis in humans, while the tsetse fly transmits trypanosomes of Trypanosoma brucei, which is the 
causative agent of human African trypanosomiasis (HAT), also known as sleeping sickness. According to the World Health Organization's (WHO) statistics, there are 12 million people currently affected by leishmaniasis in 88 countries, and about 350 million people are at risk. Approximately 500,000 people in sub-Saharan Africa are infected annually with the African trypanosome (T. brucei), leading to thousands of deaths [1]. The socio-economic impact of the morbidity and mortality caused by these protozoan parasites is significant, particularly in tropical and subtropical countries [2,3].

In the last few decades, there has been an increased focus on developing treatments for African trypanosomiasis. Although several antitrypanosomal agents from plants have been characterized, great efforts are still needed to search for more antiparasitic compounds that have been evolutionarily derived from nature.

The bite of a tsetse fly is responsible for the transmission of T. brucei, which quickly adapts to the mammalian host and becomes the bloodstream form (BSF). The metabolism of host glucose through glycolysis is essential for the BSF parasite to successfully infect the host. In BSF parasites, the glycolysis of host glucose provides the sole source of ATP production. The transfer of a phosphoryl group from ATP to glucose in glycolysis is catalyzed by hexokinases (HK). T. brucei expresses two hexokinase genes encoding T. brucei hexokinase 1 (TbHK1) and 2 (TbHK2), enzymes which are essential for the BSF parasite.

The Hypericum genus belonging to the Hypericaceae family has been reported to be a prolific source of various secondary metabolites, such as flavonoids, prenylated phloroglucinols, naphthodianthrones, and volatile oils, with a wide range of biological activities, such as antidepressant, antiseptic, wound-healing, antioxidant, antiviral, antiinflammatory and antidiabetic. Recently, studies on several Hypericum species have reported their antimicrobial activity against a number of bacterial and fungal strains [4-6].

The present study investigates the antileishmanial activity against $L$. donovani (promastigotes, axenic amastigotes and intracellular amastigotes in THP1 cells), and the antitrypanosomal activity against T. brucei, of the fractions and isolated compounds of Hypericum afrum Lam. Quercetin (1) and myricetin (4) were discovered to have higher activity against T. brucei. Further virtual studies were carried out on TbHK1 as a target enzyme for investigating the probable mechanism of quercetin's and myricetin's inhibition of parasitic growth. Quercetin and myricetin bind to TbHK1 proximal to the active site, and could be cytotoxic to the African Trypanosoma parasite as a result of TbHK1 inhibition.

\section{Results}

\subsection{Chemistry}

Compounds 1-7 were identified as quercetin (1), myricitrin (2), biapigenin (3), myricetin (4), hyperoside (5), myricetin-3-O- $\beta$-D-galactopyranoside (6) and myricetin-3'-O- $\beta$-Dglucopyranoside (7) [7-13]. Compound 7 was isolated from the genus hypericum for the first time. All the compounds were tested in vitro for their antiprotozoal activity. Pentamidine was used as a positive control drug in the antileishmanial assays, while DMFO ( $\alpha$-difluoromethylornithine) was used as the positive control drug in the antitrypanosomal assay, which showed $\mathrm{IC}_{50}$ and $\mathrm{IC}_{90}$ values of 3.634 and $8.804 \mu \mathrm{M}$, respectively.

\subsection{Antiprotozoal Activity}

In this study, the in vitro antiprotozoal activities were evaluated for the Hypericum afrum aerial parts' fractions $\left(\mathrm{CHCl}_{3}\right.$, EtOAc and $n$-butanol) and isolated pure compounds 1-7 (Figure 1; see also Supplementary Materials) against T. brucei. The fractions and pure compounds were also tested against $L$. donovani promastigotes, axenic amastigotes and intracellular amastigotes in THP1 cells, for the determination of general toxicity using standard experimental procedures. 
<smiles>[R]Oc1c(-c2ccc(O)c(O)c2)oc2cc(O)cc(O)c2c1=O</smiles>

1, $\mathrm{R}=\mathrm{H}$

5, R = galactopyranosyl<smiles>[R2]Oc1c(-c2cc([R20])c(O)c(O)c2)oc2cc(O)cc(O)c2c1=O</smiles>

2, $\mathrm{R}_{1}=\mathrm{H} ; \mathrm{R}_{2}=$ Rhanmosyl

4, $\mathrm{R}_{1}, \mathrm{R}_{2}=\mathrm{H}$

6, $\mathrm{R}_{1}=\mathrm{H} ; \mathrm{R}_{2}=$ Galactopyranosyl

7, $\mathrm{R}_{1}=$ Glucopyranosyl; $\mathrm{R}_{2}=\mathrm{H}$<smiles>O=c1c(-c2c(O)cc(O)c3c(=O)cc(-c4ccc(O)cc4)oc23)c(-c2ccc(O)cc2)oc2cc(O)cc(O)c12</smiles>

3

Figure 1. Structure of isolated compounds (1-7).

None of the fractions or pure compounds showed in vitro antileishmanial activities (Tables 1 and 2). Regarding the antitrypanosomal activity, the chloroform, ethyl acetate and n-butanol fractions of $H$. afrum showed significant inhibitory activity against $T$. brucei culture, with $\mathrm{IC}_{50}$ values of $12.35,13.53$ and 12.93 and with $\mathrm{IC}_{90}$ values of $14.94,19.31$ and $18.67 \mu \mathrm{g} / \mathrm{mL}$, respectively. Only compounds 1 and $\mathbf{4}$ from the ethyl acetate fraction were found to have antitrypanozomal activity. All the samples were simultaneously tested against THP1 cell for the determination of general cytotoxicity.

Compounds 1 and 4 showed potent activity against $T$. brucei at $\mathrm{IC}_{50}$ values of 7.52 and 5.71 and $\mathrm{IC}_{90}$ values of 9.76 and $7.97 \mu \mathrm{M}$, respectively (Table 1).

\subsection{Molecular Modeling Study}

It is worth noting that the bloodstream form of T. brucei is reliant on the glycolytic pathway to generate energy using host glucose as a sole source. Due to the limited homology between the host and T. brucei glycolytic enzymes, this makes Hexokinase (TbHK1) a good drug target. Inhibitors of TbHK1 are trypanocidal, with low expected side effects.

A BLAST homology search identified Hexokinase KlHxk1 of the Kluyveromyces lactis (PDB Accession code: $3 \mathrm{O} 08$ ) as the most suitable template. KlHxk1 was crystalized with a high resolution of $2 \AA$. The target and template share 31\% sequence identity and $51 \%$ similar amino acids, and only $3 \%$ gaps were detected. Using protein family information from PFAM, 14 amino acids were identified as having strictly conserved aligned positions of the Hexokinase family, with E-values of $1.7 \times 10^{-60}$, including Thr60, Gly84, Gly92, Arg97, Gly157, Phe158, Phe160, Ser161, Pro163, Leu174, Trp177, Lys179, Asp214 and Gly217 (Figure 2). Three major pockets were detected by Fpocket, one of which overlaps with the possible sugar binding site (Figure 3). This site was selected for the docking of the compounds. Myricetin showed a docking score of -8.31 (and IFD score: -743.41 ), compared to -6.62 (IFD score: -735.48 ) for quercetin. The two compounds occupied the same pocket with very similar conformation (Figure 4).

Quercetin exhibited hydrogen bonds with Ser161, Arg176, Thr178, Thr215 and Glu269, and $\pi-\pi$ interaction with Phe162. The additional hydroxyl group in myricetin did not provide extra important interaction with the surrounding amino acids. On the other hand, some of the interactions were lost, which could be attributed to a slight shifting of the interacting functional groups of myricetin to allow for a proper placement of the additional hydroxyl group inside the binding site. Molecular dynamics (MD) simulations were conducted for $50 \mathrm{~ns}$ to study the stability and strength of ligand binding. The root means square deviation (RMSD) is used as an indicator for interaction stability. 
Table 1. Antiprotozoal activity and cytotoxicity of isolated compounds of H. afrum.

\begin{tabular}{|c|c|c|c|c|c|c|c|c|c|c|c|}
\hline $\begin{array}{l}\text { Compounds } \\
\text { Codes }\end{array}$ & Compounds Names & $\begin{array}{l}\text { L. Donovani } \\
\text { Promastigote } \\
\text { IC }_{50}(\mu \mathrm{M})\end{array}$ & $\begin{array}{c}\text { L. Donovani } \\
\text { Promastigote } \\
\text { IC }_{90}(\mu \mathrm{M})\end{array}$ & $\begin{array}{c}\text { L. Donovani } \\
\text { Amastigote } \\
\mathrm{IC}_{50}(\mu \mathrm{M})\end{array}$ & $\begin{array}{l}\text { L. Donovani } \\
\text { Amastigote } \\
\text { IC }_{90}(\mu \mathrm{M})\end{array}$ & $\begin{array}{l}\text { L. Donovani } \\
\text { Amastig- } \\
\text { ote/THP1 } \\
\text { IC }_{50}(\mu \mathrm{M})\end{array}$ & $\begin{array}{c}\text { L. Donovani } \\
\text { Amastig- } \\
\text { ote/THP1 IC } 90 \\
(\mu \mathrm{M})\end{array}$ & $\begin{array}{c}\text { T. Brucei } \\
\text { IC }_{50}(\mu \mathrm{M})\end{array}$ & $\begin{array}{c}\text { T. Brucei } \\
\text { IC } 90(\mu \mathrm{M})\end{array}$ & $\begin{array}{c}\text { THP1 } \\
\text { Cytotoxicity } \\
\text { IC }_{50}(\mu \mathrm{M})\end{array}$ & $\begin{array}{c}\text { THP1 } \\
\text { Cytotoxicity } \\
\text { IC }_{90}(\mu \mathrm{M})\end{array}$ \\
\hline AMB & Amphotericin & 0.136 & 0.215 & 0.211 & 0.374 & 0.188 & 0.421 & NT & NT & $>2$ & $>2$ \\
\hline PENT & Pentamidine & 1.478 & 2.382 & 9.581 & $>10$ & 1.157 & 5.587 & 0.001 & 0.002 & $>10$ & $>10$ \\
\hline DFMO & difluoromethylornithine & NT & NT & NT & NT & NT & NT & 3.634 & 8.804 & NT & NT \\
\hline 1 & Quercetin & $>10$ & $>10$ & $>10$ & $>10$ & $>10$ & $>10$ & 7.52 & 9.76 & $>10$ & $>10$ \\
\hline 2 & Miricitrin & $>10$ & $>10$ & $>10$ & $>10$ & $>10$ & $>10$ & $>10$ & $>10$ & $>10$ & $>10$ \\
\hline 3 & Biapigenin & $>10$ & $>10$ & $>10$ & $>10$ & $>10$ & $>10$ & $>10$ & $>10$ & $>10$ & $>10$ \\
\hline 4 & Myricetin & $>10$ & $>10$ & $>10$ & $>10$ & $>10$ & $>10$ & 5.71 & 7.97 & $>10$ & $>10$ \\
\hline 5 & Hyperoside & $>10$ & $>10$ & $>10$ & $>10$ & $>10$ & $>10$ & $>10$ & $>10$ & $>10$ & $>10$ \\
\hline 6 & $\begin{array}{l}\text { Myricetin-3-O- } \beta \text {-D- } \\
\text { glucopyranoside }\end{array}$ & $>10$ & $>10$ & $>10$ & $>10$ & $>10$ & $>10$ & $>10$ & $>10$ & $>10$ & $>10$ \\
\hline 7 & Cannabiscitrin & $>10$ & $>10$ & $>10$ & $>10$ & $>10$ & $>10$ & $>10$ & $>10$ & $>10$ & $>10$ \\
\hline
\end{tabular}

NT, not tested; IC-50 and IC-90 values are expressed as $\mu \mathrm{M}$ and are the mean \pm S.D. of duplicate observations. Tested concentrations range: $0.4-10 \mathrm{ug} / \mathrm{mL}$.

Table 2. Antiprotozoal activity and cytotoxicity of H. afrum fractions.

\begin{tabular}{|c|c|c|c|c|c|c|c|c|c|c|c|}
\hline Fractions & $\begin{array}{c}\text { L. Donovani } \\
\text { Promastig- } \\
\text { ote } \\
\mathrm{IC}_{50} \\
(\mu \mathrm{g} / \mathrm{mL})\end{array}$ & $\begin{array}{c}\text { L. Donovani } \\
\text { Promastig- } \\
\text { ote } \\
\mathrm{IC}_{90} \\
(\mu \mathrm{g} / \mathrm{mL})\end{array}$ & $\begin{array}{c}\text { L. Donovani } \\
\text { Amastigote } \\
\text { IC }_{50} \\
(\mu \mathrm{g} / \mathrm{mL})\end{array}$ & $\begin{array}{c}\text { L. Donovani } \\
\text { Amastigote } \\
\text { IC }_{90} \\
(\mu \mathrm{g} / \mathrm{mL})\end{array}$ & $\begin{array}{c}\text { L. Donovani } \\
\text { Amastig- } \\
\text { ote/THP } \\
\text { IC }_{50} \\
(\mu \mathrm{g} / \mathrm{mL})\end{array}$ & $\begin{array}{c}\text { L. Donovani } \\
\text { Amastig- } \\
\text { ote/THP } \\
\text { IC } 90 \\
(\mu \mathrm{g} / \mathrm{mL})\end{array}$ & $\begin{array}{c}\text { T. Brucei } \\
\text { IC }_{50} \\
(\mu \mathrm{g} / \mathrm{mL})\end{array}$ & $\begin{array}{c}\text { T. Brucei } \\
\text { IC }_{90} \\
(\mu \mathrm{g} / \mathrm{mL})\end{array}$ & $\begin{array}{c}\text { THP1 } \\
\text { Cytotoxicity } \\
\text { IC }_{50} \\
(\mu \mathrm{g} / \mathrm{mL})\end{array}$ & $\begin{array}{c}\text { THP1 } \\
\text { Cytotoxicity } \\
\text { IC }_{90} \\
(\mu \mathrm{g} / \mathrm{mL})\end{array}$ & $\begin{array}{l}\text { Test conc } \\
(\mu \mathrm{g} / \mathrm{mL})\end{array}$ \\
\hline $\mathrm{CHCl}_{3}$ & $>20$ & $>20$ & $>20$ & $>20$ & $>20$ & $>20$ & 12.35 & 14.94 & $>20$ & $>20$ & $20-0.8$ \\
\hline EtOAc & $>20$ & $>20$ & $>20$ & $>20$ & $>20$ & $>20$ & 13.53 & 19.31 & $>20$ & $>20$ & $20-0.8$ \\
\hline $\mathrm{BuOH}$ & $>20$ & $>20$ & $>20$ & $>20$ & $>20$ & $>20$ & 12.93 & 18.67 & $>20$ & $>20$ & $20-0.8$ \\
\hline $\mathrm{AMB}$ & 0.138 & 0.188 & 0.304 & 0.362 & 0.187 & 0.264 & NT & NT & $>2$ & $>2$ & $2.0-0.08$ \\
\hline DFMO & NT & NT & NT & NT & NT & NT & 3.634 & 8.804 & NT & NT & $20-0.8$ \\
\hline
\end{tabular}

NT, not tested; $\mathrm{IC}_{50}$ and $\mathrm{IC}_{90}$ values are expressed as $\mu \mathrm{g} / \mathrm{mL}$. 


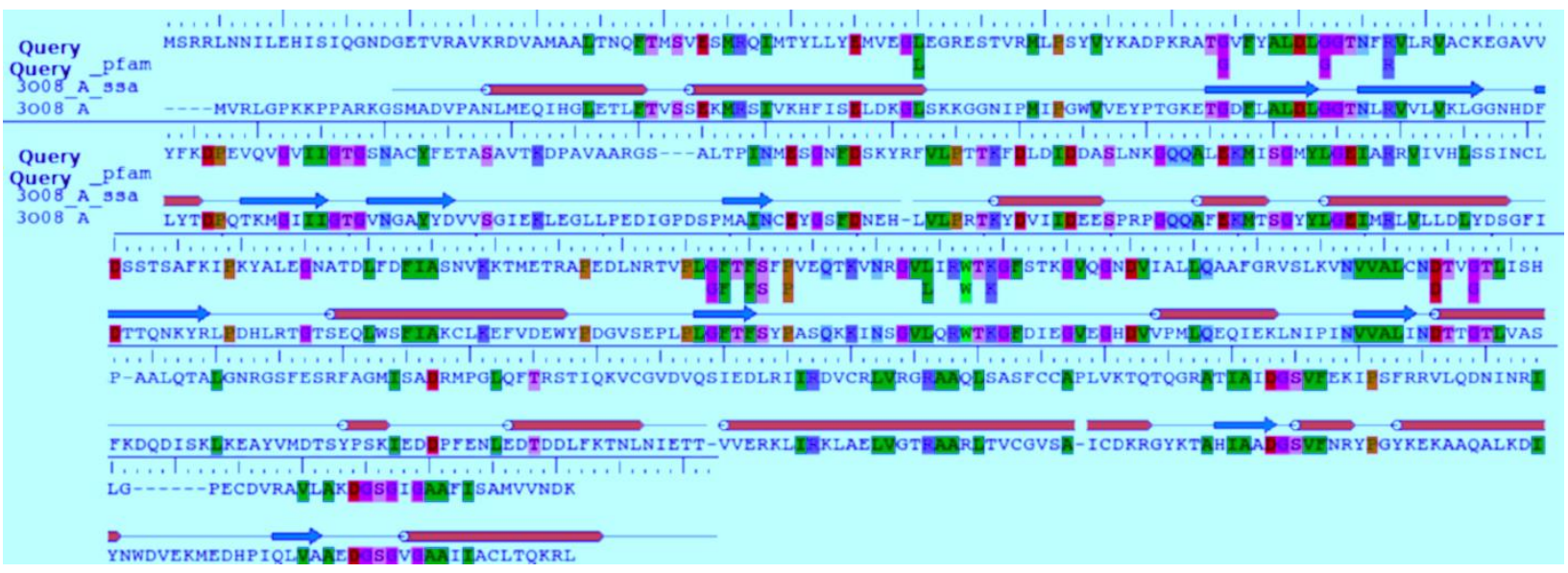

Figure 2. The secondary structure and conservation information of the target. Secondary structure predictions for the target are annotated as Hs (helices) and Es (beta sheets), while the structure of the template is shown as blue arrows for beta sheets and orange cylinders for alpha helices. Globally conserved regions are annotated as a separate row.
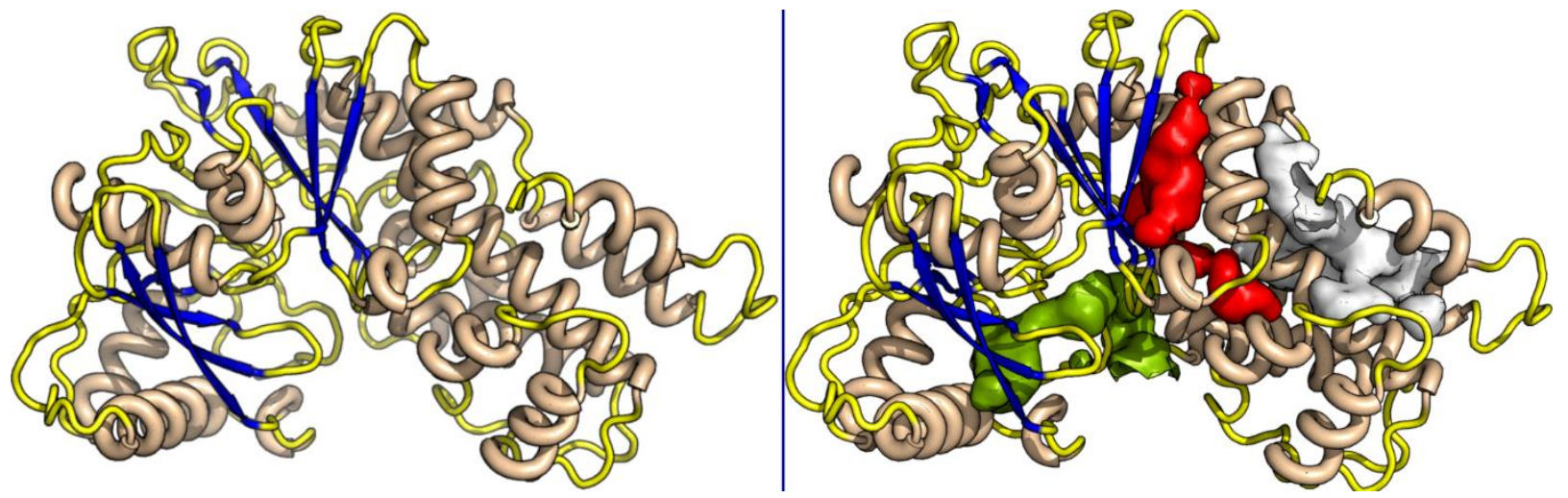

Figure 3. The 3D model of TbHK1 (left) and the most prominent pockets for ligand binding (right).
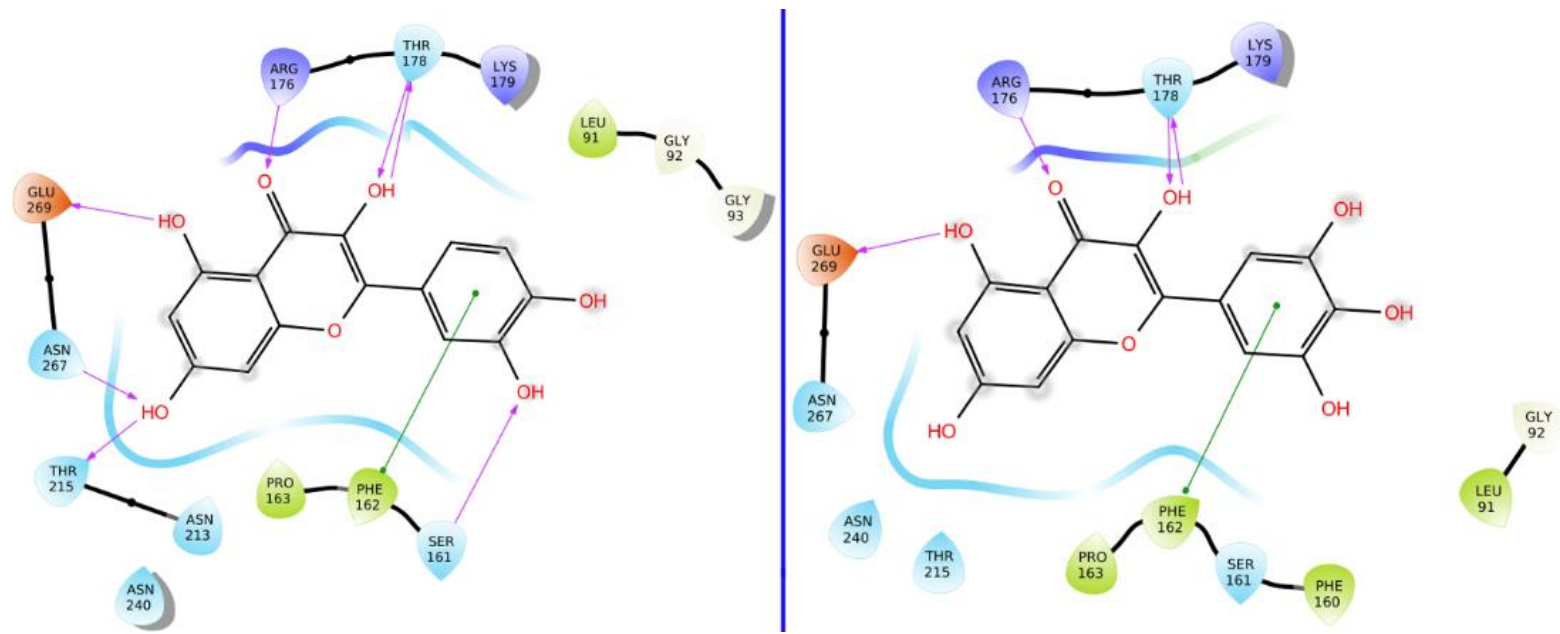

Figure 4. The 2D interaction models of quercetin (left) and myricetin (right). 


$$
R M S D_{x}=\sqrt{\frac{1}{N} \sum_{i=1}^{N}\left(r_{i}^{\prime}\left(t_{x}\right)-r_{i}\left(t_{r e f}\right)\right)^{2}}
$$

$N$ is the number of atoms in the system,

$t_{\text {ref }}$ is the reference time,

$r_{i}^{\prime}$ is the position of the selected atoms (i) in frame $x$,

$t_{x}$ is the record time of frame $x$.

Myricetin showed a stable pose in the binding pocket over the course of the MD time. It showed an RMSD value of $\sim 3.0 \AA$, which is comparable to the $2.4 \AA$ of the protein backbone, while quercetin showed a high RMSD value of $\sim 15.0 \AA$ compared to that of the protein backbone $(2.9 \AA)$. The binding mode of quercetin required the first $10 \mathrm{~ns}$ to adopt the most stable pose in the binding pocket (Figure 5). The reference interaction site model (RISM) solvation approach was used to investigate the location and stability of water molecules (Figures 6 and 7).

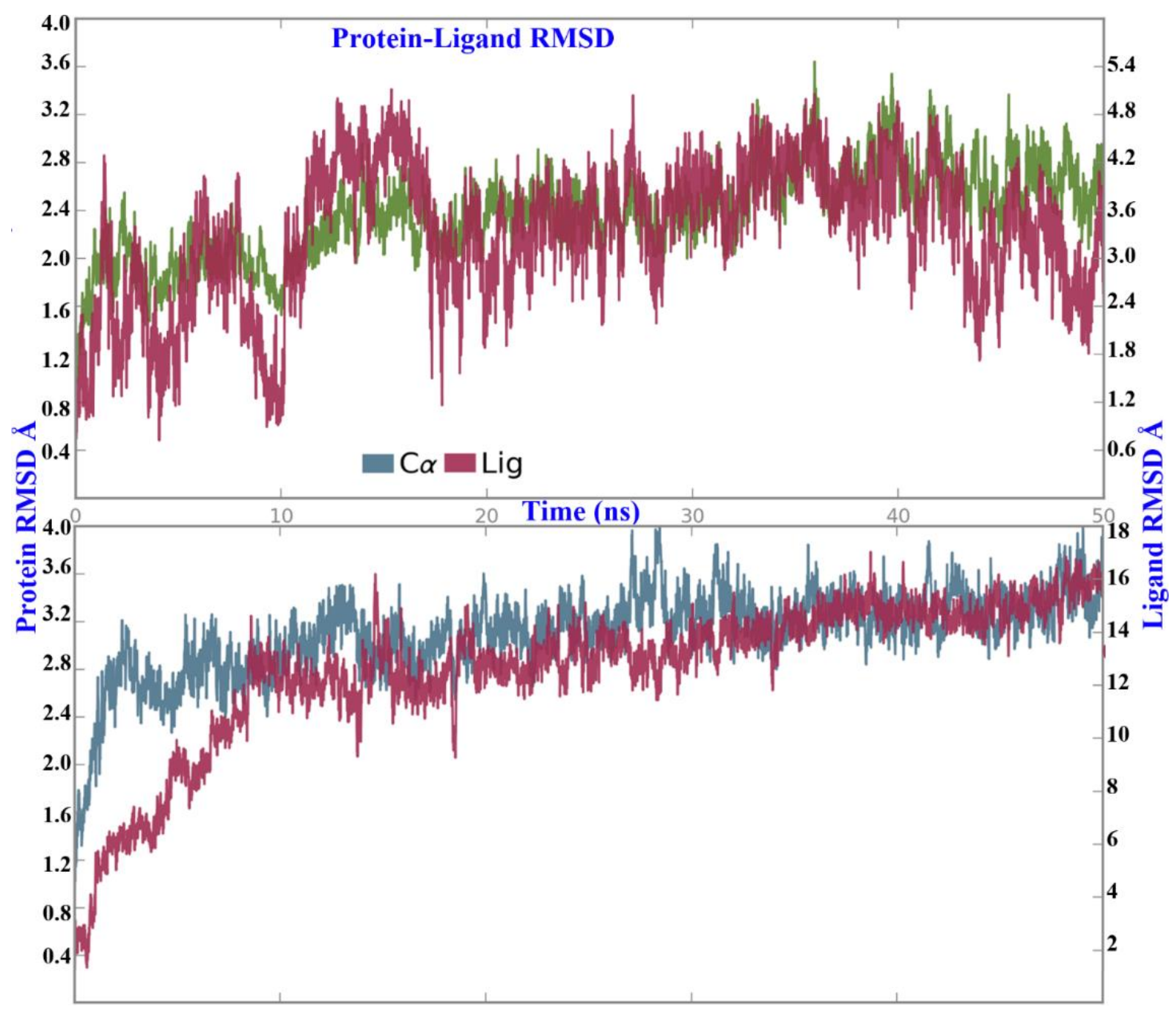

Figure 5. The RMSD of protein and ligand over the MD simulation time.

Possible water molecule locations were computed and thermodynamically analyzed. The absolute protein-ligand binding free energies were then calculated using the water swap method to rank quercetin and myricetin, by relying on the fact that protein-ligand binding is a competition between ligand and water for binding to the pocket (Figure 8). Because this approach allows for the decomposition of $\Delta \mathrm{G}$ on a per-residue basis, it permits 
the identification of which amino acid residues favor binding to ligand or water (Figure 9). The free energy of binding is calculated in $\mathrm{kcal} / \mathrm{mol}$ for each ligand with different methods, including Bennett, thermodynamic integration (TI), free energy perturbation (FEP) and TI Quadrature. The results in $\mathrm{kcal} / \mathrm{mol}$ for myricetin are as follows: Bennett, -15.34 ; TI, -14.15 ; FEP, -14.14 ; and TI Quadrature, -14.23 . Those of quercetin are Bennett, -9.92 ; TI, -9.28; FEP, -8.84; and TI Quadrature, -9.6. Then, a consensus-calculated free energy of binding was defined from a weighted arithmetic mean of the Bennett (50\%), TI (30\%), and FEP $(20 \%)$ free energy estimators. The consensus is -14.74 for myricetin and -9.51 for quercetin.
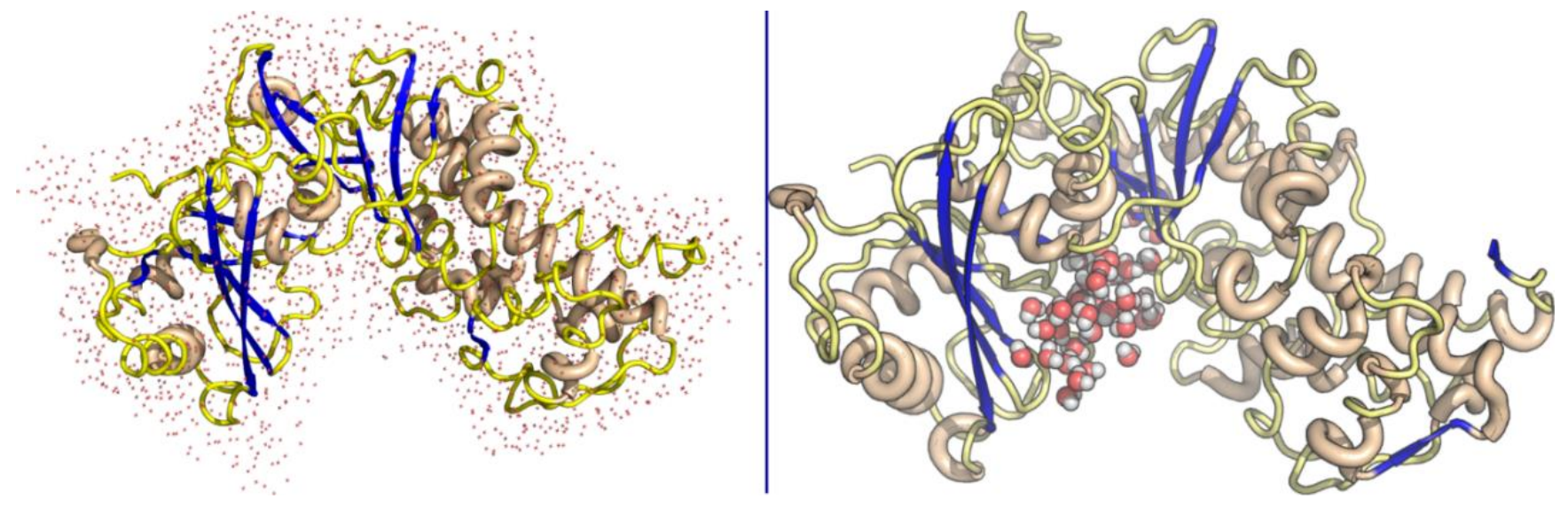

Figure 6. The solvated protein (left) and solvated binding pocket before interaction with the ligand (right).

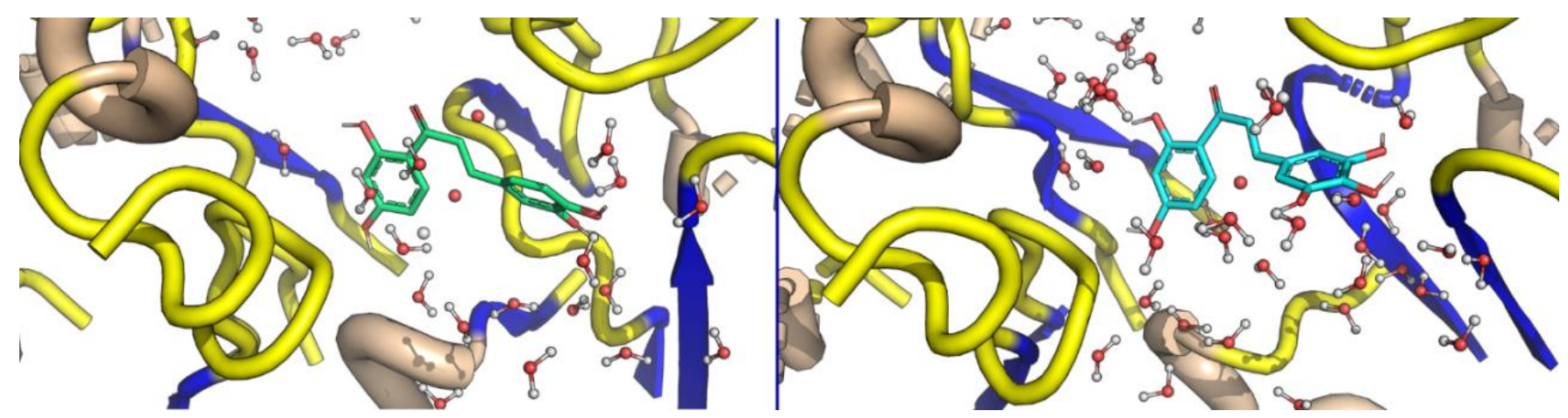

Figure 7. The ligands displace water molecules from the binding pocket. 


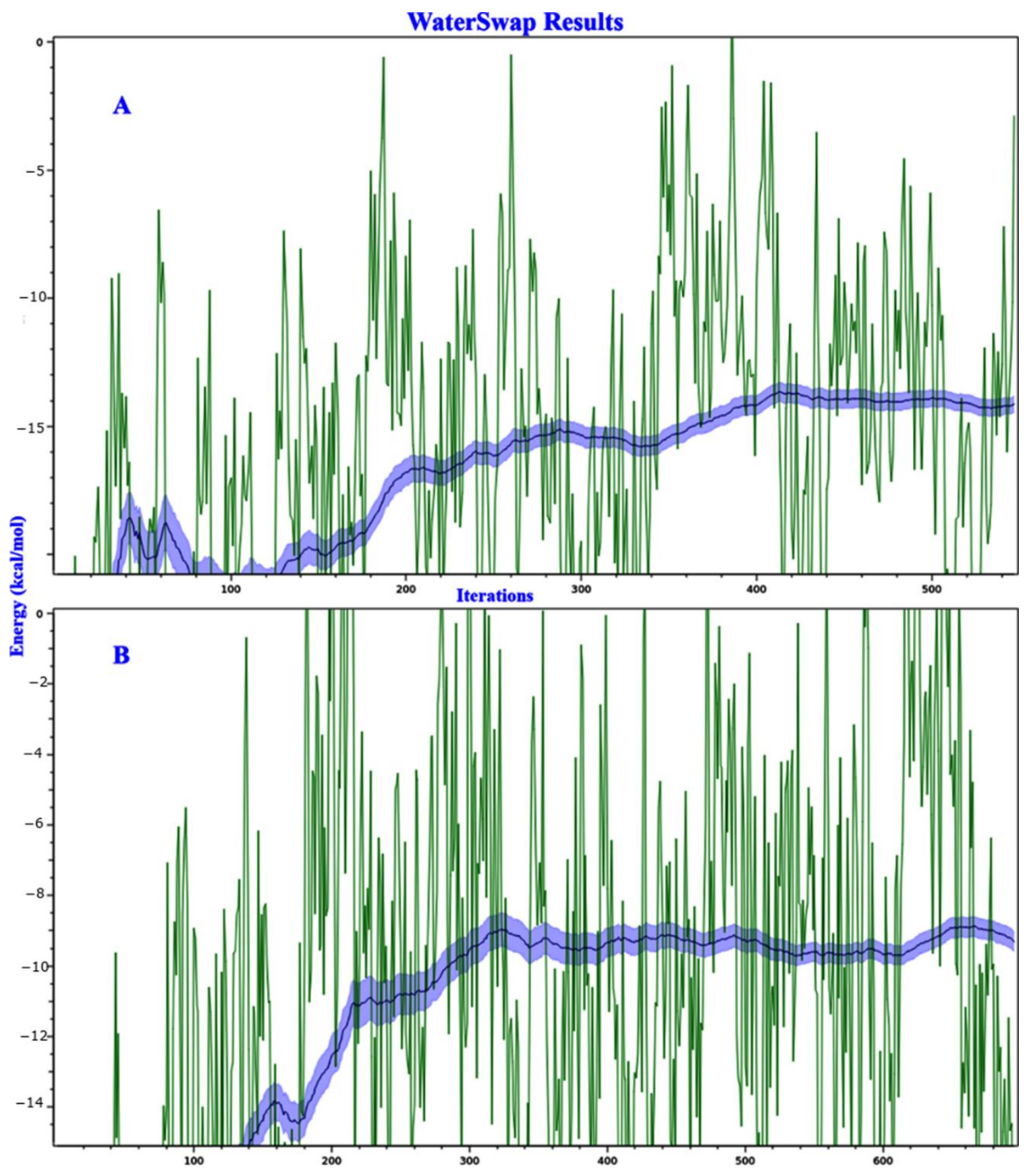

Figure 8. Water Swap results of myricetin (A) and quercetin (B). 


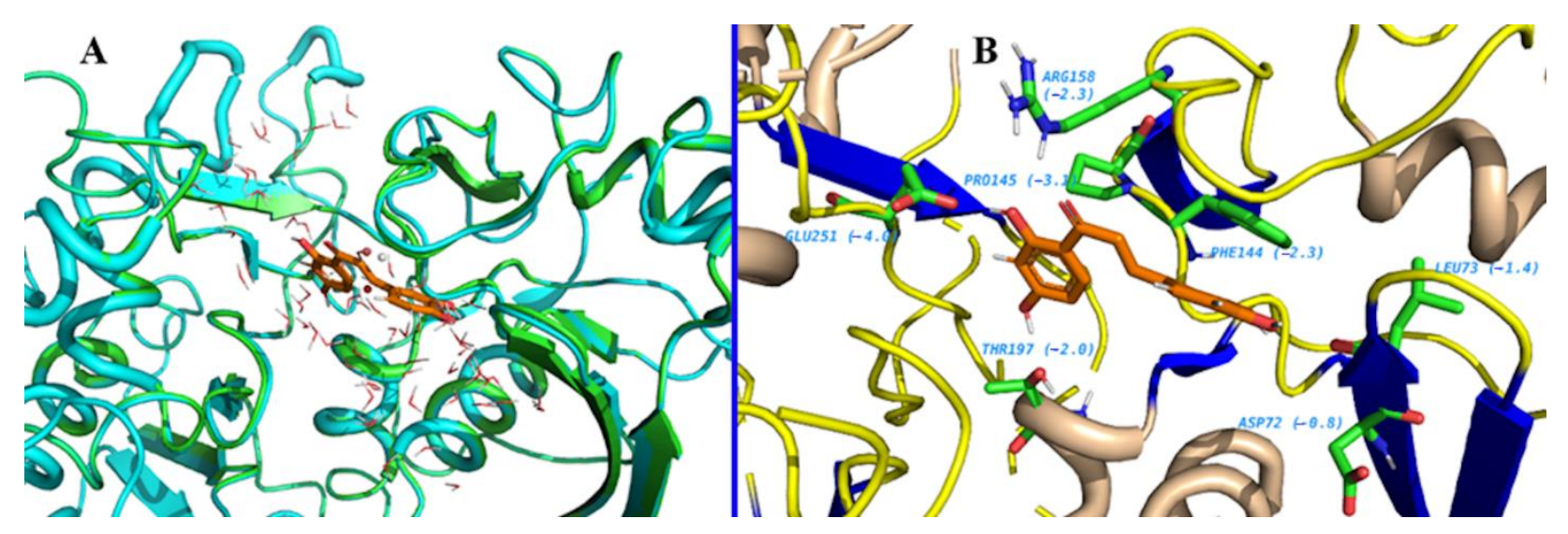

Figure 9. (A) The induced conformational changes upon ligand (quercetin) binding. The protein is shown as a cyan cartoon before binding of the ligand, and the conformational changes are shown in green. (B) The regions of the pocket that favor ligand chemistry are shown as green sticks. The free energy $(\Delta G)$ of each amino acid is shown in parenthesis; the more negative, the better.

\section{Discussion}

Flavonoids isolated from different natural resources were reported to exhibit moderate to high in vitro antitrypanosomal activity against $T$. brucei. Our results showed that the chloroform, ethyl acetate and $n$-butanol fractions of $H$. afrum exhibited potent antitrypanosomal activity against $T$. brucei, with $\mathrm{IC}_{50}$ values of $12.35,13.53$ and 12.93 and with $\mathrm{IC}_{90}$ values of $14.94,19.31$ and $18.67 \mu \mathrm{g} / \mathrm{mL}$, respectively. Quercetin and myricetin were isolated from the EtOAc fraction, and showed good activity towards T. brucei, with $\mathrm{IC}_{50}$ values of 7.52 and 5.71, and $\mathrm{IC}_{90}$ values of 9.76 and $7.97 \mu \mathrm{M}$, respectively. A future examination of the chloroform and $n$-butanol fractions might yield bioactive molecules.

Quercetin and structurally related flavonoids possess several biological and pharmacological activities. Quercetin and myricetin are dietary flavonoids with promising activities, including antioxidant, anti-inflammatory, cardiovascular, and others $[14,15]$. The mechanism of action for quercetin and myricetin as antiparasitics has been postulated as follows: these flavonoids can disrupt the mitochondrial function on the parasites, and most likely inhibit different enzymes, including shock proteins, topoisomerases and kinases, among others. They could also show indirect activity through the induction of microbicidal responses, for example, the production of various cytokines and the production of nitric oxide [16]. Hexokinase (TbHK1) enzymes have been shown to be promising targets on T. brucei $[17,18]$. Quercetin and myricetin were identified as inhibitors of TbHK1, and showed $\mathrm{IC}_{50}$ values of 4.1 and $48.9 \mu \mathrm{M}$, respectively [16]. These results support the idea of considering TbHK1 as a target for antiparasitic activities. These results were further confirmed by our computational studies.

Quercetin has been reported as a potent antileishmanial agent; however, in our study, we did not find it [19].

\section{Material and Methods}

\subsection{General Experimental Procedures}

Melting points were determined on an Opti-Melt automated melting point system (Stanford Research Systems), and were uncorrected. IR spectra were recorded using an Agilent model Cary 630 FT-IR. Optical rotations were recorded using a Rudolph Research Analytical Autopol V Polarimeter. UV was obtained using a Perkin-Elmer Lambda 3B $\mathrm{UV} /$ vis spectrophotometer. ${ }^{1} \mathrm{H}$ - and ${ }^{13} \mathrm{C}$-NMR spectra were obtained on Bruker model AMX 500 and 400 NMR spectrometers with standard pulse sequences, operating at 500 and $400 \mathrm{MHz}$ in ${ }^{1} \mathrm{H}$ and 125 and $100 \mathrm{MHz}$ in ${ }^{13} \mathrm{C}$. The coupling constants were recorded in Hertz (Hz). Standard pulse sequences were used for COSY, HMQC, HMBC and DEPT. All spectra were run at $25^{\circ} \mathrm{C}$. High-resolution mass spectra (HRMS) were measured on 
a Micromass Q-Tof Micro mass spectrometer with a lock spray source. Column chromatography was carried out on silica gel (70-230 mesh, Merck, Darmstadt, Germany), C18 SPE (500 mg Bed, Thermo scientific, Waltham, MA, USA), Diaion HP-20 (Sorbetch technologies, Norcross, GA, USA), MN-polyamide-SC-6 (Sigma Aldrich, St Louis, MO, USA) and Sephadex LH-20 (Sigma Aldrich, St Louis, MO, USA). TLC (silica gel 60 F254, EmD Millipore Sigma, Darmstadt, Germany) was used to monitor the fractions from column chromatography. Preparative TLC was carried out on silica gel 60 PF254 + 366 plates $(20 \mathrm{~cm} \times 20 \mathrm{~cm}, 1 \mathrm{~mm}$ thick). Visualization of the TLC plates was achieved with a UV lamp $(\lambda=254$ and $365 \mathrm{~nm})$ and an anisaldehyde/acid spray reagent (MeOH-acetic acid-anisaldehyde-sulfuric acid, 85:9:1:5). The absolute configurations of the sugar moieties of all tested flavonoid glycosides have been identified by the UPLC-UV/MS method [20].

\subsection{Plant Material}

The aerial parts of Hypericum afrum (Lam.) were collected from the El Kala region, El Tarf, in northeastern Algeria, in July 2011. A voucher specimen (UM-10012014) was deposited in the culture collection of the Department of BioMolecular Sciences, University of Mississippi.

\subsection{Extraction and Isolation}

Extraction and isolation. Dried powdered aerial parts (1000 g) of H. afrum were macerated at room temperature with $\mathrm{EtOH}-\mathrm{H}_{2} \mathrm{O}(80: 20, v / v)$ over $24 \mathrm{~h}$, three times. The filtered solvents were combined and evaporated under vacuum at a temperature of $40{ }^{\circ} \mathrm{C}$ to give a residue $(30 \mathrm{~g})$. The obtained extract was suspended in water $(800 \mathrm{~mL})$ and successively partitioned with $\mathrm{CHCl}_{3}$, EtOAc and $n$-butanol, yielding $500 \mathrm{mg}\left(\mathrm{CHCl}_{3}\right), 7 \mathrm{~g}$ (EtOAc) and $12 \mathrm{~g}$ ( $n$-butanol) fractions, respectively.

The EtOAc fraction $(7 \mathrm{~g})$ was chromatographed on a silica gel column and eluted with a $\mathrm{CH}_{2} \mathrm{Cl}_{2}-\mathrm{MeOH}$ solvent system of increasing polarity to yield 10 subfractions (E-1-10) according to their TLC behavior. The subfraction E-3 $(115 \mathrm{mg})$ was further chromatographed on the column of a Sephadex $\mathrm{LH}-20$ with $\mathrm{CH}_{2} \mathrm{Cl}_{2}-\mathrm{MeOH}$ (1:1) as the eluent yielding compound $1(16 \mathrm{mg})$ as a yellow precipitate. A yellow precipitate was obtained from the subfraction E-7 ( $40 \% \mathrm{MeOH}$ in $\mathrm{CH}_{2} \mathrm{Cl}_{2}$ ). The solid was combined and subjected to a column of Sephadex LH-20 eluted with methanol to furnish compound $2(7 \mathrm{mg})$. The subfraction E$4(10 \% \mathrm{MeOH})(423 \mathrm{mg})$ was chromatographed on Sephadex LH-20 eluted with methanol to furnish compound $3(10 \mathrm{mg})$. Subfraction E-5 $(125 \mathrm{mg})$ was chromatographed on a Sephadex LH-20 column with Methanol and further purified by preparative TLC eluted with $\mathrm{CHCl}_{3}-\mathrm{MeOH}$ (10:1) to afford compound 4 (15 mg).

The $n$-butanol fraction (12 g) was subjected to column chromatography over Diaion HP-20 to afford three subfractions: $\mathrm{A}\left(\mathrm{H}_{2} \mathrm{O} 100 \%\right), \mathrm{B}(50 \% \mathrm{Me} 0 \mathrm{H}$ in water) and $\mathrm{C}(100 \%$ $\mathrm{MeOH})$. Subfraction $\mathrm{C}(8 \mathrm{~g})$ was subjected to polyamide column chromatography to give 13 subfractions (C-I to C-XIII). Then, $5 \mathrm{~g}$ of the subfraction C-X ( $100 \%$ methanol) was chromatographed on MN-polyamide-SC-6 CC (250 g), eluted with water to equilibrate, then with gradient-decreased polarities with a water-methanol system to yield 8 subfractions (C-X-1 to C-X-8). Subfraction C-X-4 (50 mg) was further subjected to a column of Sephadex LH-20 (20 g) eluted with $\mathrm{MeOH}-\mathrm{CH}_{2} \mathrm{Cl}_{2}$ (1:1) to afford compound 5 (4.0 mg). C-X-5 (70 $\mathrm{mg}$ ) was subjected to a column of Sephadex LH-20 (30 g) eluted with $\mathrm{MeOH}-\mathrm{CH}_{2} \mathrm{Cl}_{2}$ (1:1) to afford compounds $6(5.0 \mathrm{mg})$ and $7(10.6 \mathrm{mg})$.

\subsection{In Vitro Antileishmanial and Antitrypanosomal Assays}

The in vitro antileishmanial and antitrypanosomal assays were performed on cell cultures of L. donovani promastigotes, axenic amastigotes, THP1-amastigotes, and Trypanosoma brucei trypomastigotes, by Alamar Blue assays [21]. The conditions for seeding the THP1 cells, the exposure to the test samples and the evaluation of cytotoxicity were the same as described in the parasite rescue and transformation assay [22]. $\mathrm{IC}_{50}$ and $\mathrm{IC}_{90}$ values were computed from the dose-response curves using XLfit software. DFMO (difluoromethy- 
lornithine) was used as the positive control. The antiprotozoal activities of the H. afrum fractions and isolated compounds were evaluated in vitro against $L$. donovani promastigotes, axenic amastigotes and intracellular amastigotes in THP1 cells. The fractions and some isolated compounds were also evaluated against $T$. brucei trypomastigote forms. All the fractions and compounds were simultaneously tested against THP1 cell for the determination of general cytotoxicity [22].

\subsection{Methods: Molecular Modeling}

The amino acid sequence of TbHK1 was downloaded from the Uniprot database (www.uniprot.org)(accessed on 1 December 2019). Prime was used to build the 3D model of the target [23-25]. To find the appropriate template, a BLAST homology search was initiated with default options. The globally conserved residues were also identified through the standard Prime search algorithm. The alignment between the target sequence and the template was calculated to define the complementary secondary structure information using the Prime STA option. An all-atom model was constructed using the knowledgebased method. Hydrogen bond assignment and restrained minimization options were used to fix and relax the generated model. Loop refinement was performed for the model to optimize the loops' conformation. Fpocket [26] was then used to detect the ligand binding sites in the model. We used Glide for the molecular docking step. The receptor grid was prepared by selecting the amino acids defining the pocket detected by Fpocket. To allow for more space for the ligands in the binding pocket, scaling of the van der Waals radii by a factor of 0.8 was employed to soften the potential of the nonpolar parts of the receptor. The prepared ligands were docked using Glide SP docking precision [27-31]. The best-docked pose was saved for each ligand. Then, these poses were used for the molecular dynamics simulation [32,33], 3D-RISM [34-37] and WaterSwap [38,39] steps. The two complexes were solvated in an orthorhombic box using a TIP4P water solvation model in Desmond System Builder. Appropriate numbers of sodium ions were added to the system to neutralize the net charge on the protein. The OPLS3 force field was selected for the simulation run. After a series of energy minimizations and short simulations, the NPT ensemble was set for the MD production step. Intervals of 25 ps were used to save the coordinates and the MD simulations were set for $50 \mathrm{~ns}$. The protein-ligand complex was prepared as recommended for the 3D-RISM calculation. The grid was defined for the whole protein and the calculation was performed using the XED force field. We used a grid spacing of $0.3 \AA$ with a grid external width of $14.0 \AA$. The convergence tolerance was set to $10^{-8}$ and the total formal charge was neutralized with counter ions. A WaterSwap calculation was conducted for the ligands. The normal calculation method was chosen. The charge method was set to Gasteiger, and the solvation box buffer dimension was defined as $10.0 \AA$. The system was equilibrated for 100 ps using OpenMM.

\section{Conclusions}

The in vitro antitrypanosomal evaluation of the Hypericum afrum Lam. species against T. brucei revealed that the $\mathrm{CHCl}_{3}, \mathrm{EtOAc}$ and $\mathrm{BuOH}$ fractions possess potent antitrypanosomal activity. Furthermore, the fractionation of these fractions led to the isolation and characterization of quercetin and myricetin as the potent components. Quercetin (1) and myricetin (4) showed good antitrypanosomal activity towards T. brucei, with IC $\mathrm{I}_{50}$ and IC 90 values of 7.52 and 5.71 , and 9.76 and $7.97 \mu \mathrm{M}$, respectively.

The present study reports for the first time the antiprotozoal properties of the Algerian species Hypericum afrum Lam., contributing to the phytochemical and pharmacological knowledge of this species. Moreover, this species could be a source of new antitrypanosomal agents.

The mechanism of antitrypanosomal activity was investigated using molecular docking studies on the potential target enzyme T. brucei Hexokinase (TbHK1). Docking studies of molecules (1) and (4) revealed their strong affinity towards Hexokinase (TbHK1) as a target of T. brucei. 
Supplementary Materials: The following are available online, Figure S1: ${ }^{1} \mathrm{H}-\mathrm{NMR}$ spectrum of compound 1, Figure S2: ${ }^{13} \mathrm{C}-\mathrm{NMR}$ spectrum of compound 1, Figure S3: Positive HRESIMS of compound 1, Figure S4: ${ }^{1} \mathrm{H}-\mathrm{NMR}$ spectrum of compound 2, Figure S5: ${ }^{13} \mathrm{C}-\mathrm{NMR}$ spectrum of compound 2, Figure S6: Negative HRESIMS of compound 2, Figure S7: ${ }^{1} \mathrm{H}-\mathrm{NMR}$ spectrum of compound 3, Figure S8: ${ }^{13} \mathrm{C}-\mathrm{NMR}$ spectrum of compound 3, Figure S9: Positive HRESIMS of compound 3, Figure S10: ${ }^{1} \mathrm{H}-\mathrm{NMR}$ spectrum of compound 4, Figure S11. ${ }^{13} \mathrm{C}-\mathrm{NMR}$ spectrum of compound 4, Figure S12: Negative HRESIMS of compound 4. Figure S13: ${ }^{1} \mathrm{H}-\mathrm{NMR}$ spectrum of compound 5, Figure S14: ${ }^{13} \mathrm{C}-\mathrm{NMR}$ spectrum of compound 5, Figure S15: Negative HRESIMS of compound 5, Figure S16: ${ }^{1} \mathrm{H}-\mathrm{NMR}$ spectrum of compound 6, Figure S17: ${ }^{13} \mathrm{C}-\mathrm{NMR}$ spectrum of compound 6, Figure S18: Negative HRESIMS of compound 6, Figure S19: ${ }^{1} \mathrm{H}-\mathrm{NMR}$ spectrum of compound 7, Figure S20: ${ }^{13}$ C-NMR spectrum of compound 7, Figure S21: Negative HRESIMS of compound 7.

Author Contributions: Conceptualization, F.L. (Farida Larit), K.M.E., M.A.N. and F.L. (Francisco León); methodology, F.L. (Farida Larit), K.M.E., M.A.N. and F.L. (Francisco León); software, F.L. (Farida Larit) K.M.E., M.A.N. and F.L. (Francisco León); validation, F.L. (Farida Larit), K.M.E., M.A.N., M.M.G. and F.L. (Francisco León); formal analysis, F.L. (Farida Larit), K.M.E., M.A.N. and F.L. (Francisco León); investigation, F.L. (Farida Larit), K.M.E., M.A.N. and F.L.(Francisco León); resources, F.L. (Farida Larit), K.M.E., M.A.N., F.L. (Francisco León), M.M.G., S.J.C.; data curation, F.L. (Farida Larit), K.M.E., M.A.N.; writing - original draft preparation, F.L. (Farida Larit), K.M.E., M.A.N.; writing—review and editing, F.L. (Farida Larit), K.M.E., M.A.N., M.M.G. and F.L. (Francisco León); visualization, F.L. (Farida Larit), K.M.E., M.A.N. and F.L. (Francisco León); supervision, F.L. (Farida Larit), K.M.E., M.A.N., F.L. (Francisco León) and S.J.C.; project administration, F.L. (Farida Larit), S.B., S.J.C. and F.L. (Francisco León); funding acquisition, M.M.G. All authors have read and agreed to the published version of the manuscript.

Funding: This research was funded in part by grant numbers P20GM104932 and P30GM122733 from the National Institute of General Medical Sciences (NIGMS), a component of the National Institutes of Health (NIH), and was conducted in part in a facility constructed with support from the Research Facilities Improvements Program (C06RR14503) from the NIH National Center for Research Resources; its contents are solely the responsibility of the authors and do not necessarily represent the official view of NIGMS or NIH.

Data Availability Statement: Data is available from the authors.

Acknowledgments: We are grateful to the Algerian Ministry of Higher Education and Scientific Research and the University of Mississippi, School of Pharmacy, Mississippi, USA and AlMaarefa University for their financial support. We are especially thankful to Babu Tekwani and Melissa Jacob for providing the antiprotozoal assays.

Conflicts of Interest: The authors declare no conflict of interest.

Sample Availability: Samples of the compounds 1-7 are available from the authors.

\section{References}

1. WHO. Available online: https://www.who.int/leishmaniasis/en/ (accessed on 23 December 2020).

2. Okwor, I.; Uzonna, J. Social and economic burden of human leishmaniasis. Am. J. Trop. Med. Hyg. 2016, 94, 489-493. [CrossRef]

3. Boelaert, M.; Meheus, F.; Robays, J.; Lutumba, P. Socio-economic aspects of neglected diseases: Sleeping sickness and visceral leishmaniasis. Ann. Trop. Med. Parasitol. 2010, 104, 535-542. [CrossRef]

4. Larit, F.; León, F.; Jasika-Misiak, I.; Wieczorek, P.; Cutler, S. Phenolic Content and Antioxidant Activity of Cytisus Villosus and Hypericum Afrum Extracts. Planta Med. 2016, 82, PB21. [CrossRef]

5. Larit, F.; León, F.; Chaurasiya, N.D.; Tekwani, B.L.; Benyahia, S.; Benayache, S.; Cutler, S.J. A new phloroglucinol derivative isolated from Hypericum afrum, a plant endemic to Algeria. Rec. Nat. Prod. 2017, 11, 77-81.

6. Larit, F.; Elokely, K.M.; Chaurasiya, N.D.; Benyahia, S.; Nael, M.A.; León, F.; Abu-Darwish, M.S.; Efferth, T.; Wang, Y.-H.; Belouahem-Abed, D. Inhibition of human monoamine oxidase A and B by flavonoids isolated from two Algerian medicinal plants. Phytomedicine 2018, 40, 27-36. [CrossRef] [PubMed]

7. Chimenti, F.; Cottiglia, F.; Bonsignore, L.; Casu, L.; Casu, M.; Floris, C.; Secci, D.; Bolasco, A.; Chimenti, P.; Granese, A. Quercetin as the active principle of Hypericum hircinum exerts a selective inhibitory activity against MAO-A: Extraction, Biological analysis, and computational study. J. Nat. Prod. 2006, 69, 945-949. [CrossRef]

8. Eldahshan, O.A. Isolation and structure elucidation of phenolic compounds of carob leaves grown in Egypt. Curr. Res. J. Biol. Sci. 2011, 3, 52-55. 
9. Miean, K.H.; Mohamed, S. Flavonoid (myricetin, quercetin, kaempferol, luteolin, and apigenin) content of edible tropical plants. J. Agric. Food Chem. 2001, 49, 3106-3112. [CrossRef] [PubMed]

10. David, J.M.; Cruz, F.G.; Guedes, M.L.S.; Chávez, J.P. Flavonol glycosides from Davilla flexuosa. J. Braz. Chem. Soc. 1996, 7, 115-118. [CrossRef]

11. Wu, Y.; Zhou, S.D.; Li, P. Determination of flavonoids in Hypericum perforatum by HPLC analysis. Yao Xue Xue Bao Acta Pharm. Sin. 2002, 37, 280-282.

12. Paul, B.; Rao, G.S.; Kapadia, G.J. Isolation of myricadiol, myricitrin, taraxerol, and taraxerone from Myrica cerifera L. root bark. J. Pharm. Sci. 1974, 63, 958-959. [CrossRef]

13. Baoliang, C.; Motoyuki, N.; Junei, K.; Toshihiro, N. Chemical constituents of Astragali semen. Chem. Pharm. Bull. 1993, 41, 178-182.

14. Semwal, D.K.; Semwal, R.B.; Combrinck, S.; Viljoen, A. Myricetin: A dietary molecule with diverse biological activities. Nutrients 2016, 8, 90. [CrossRef]

15. Salehi, B.; Machin, L.; Monzote, L.; Sharifi-Rad, J.; Ezzat, S.M.; Salem, M.A.; Merghany, R.M.; El Mahdy, N.M.; Kılıç, C.S.; Sytar, O. Therapeutic Potential of Quercetin: New Insights and Perspectives for Human Health. ACS Omega 2020, 20, 11849-11872. [CrossRef] [PubMed]

16. Dodson, H.C.; Lyda, T.A.; Chambers, J.W.; Morris, M.T.; Christensen, K.A.; Morris, J.C. Quercetin, a fluorescent bioflavanoid, inhibits Trypanosoma brucei hexokinase 1. Exp. Parasitol. 2011, 127, 423-428. [CrossRef] [PubMed]

17. Coley, A.F.; Dodson, H.C.; Morris, M.T.; Morris, J.C. Glycolysis in the african trypanosome: Targeting enzymes and their subcellular compartments for therapeutic development. Mol. Biol. Int. 2011, 2011, 123702. [CrossRef]

18. Sharlow, E.R.; Lyda, T.A.; Dodson, H.C.; Mustata, G.; Morris, M.T.; Leimgruber, S.S.; Lee, K.-H.; Kashiwada, Y.; Close, D.; Lazo, J.S. A target-based high throughput screen yields Trypanosoma brucei hexokinase small molecule inhibitors with antiparasitic activity. PLoS Negl. Trop. Dis. 2010, 4, e659. [CrossRef]

19. Mittra, B.; Saha, A.; Chowdhury, A.R.; Pal, C.; Mandal, S.; Mukhopadhyay, S.; Bandyopadhyay, S.; Majumder, H.K. Luteolin, an abundant dietary component is a potent anti-leishmanial agent that acts by inducing topoisomerase II-mediated kinetoplast DNA cleavage leading to apoptosis. Mol. Med. 2000, 6, 527-541. [CrossRef] [PubMed]

20. Wang, Y.-H.; Avula, B.; Fu, X.; Wang, M.; Khan, I.A. Simultaneous Determination of the Absolute Configuration of Twelve Monosaccharide Enantiomers from Natural Products in a Single Injection by a UPLC-UV/MS Method. Planta Med 2012, 78, 834-837. [CrossRef] [PubMed]

21. Manda, S.; Khan, S.I.; Jain, S.K.; Mohammed, S.; Tekwani, B.L.; Khan, I.A.; Vishwakarma, R.A.; Bharate, S.B. Synthesis, antileishmanial and antitrypanosomal activities of $\mathrm{N}$-substituted tetrahydro- $\beta$-carbolines. Bioorganic Med. Chem. Lett. 2014, 24, 3247-3250. [CrossRef]

22. Jain, S.K.; Sahu, R.; Walker, L.A.; Tekwani, B.L. A parasite rescue and transformation assay for antileishmanial screening against intracellular Leishmania donovani amastigotes in THP1 human acute monocytic leukemia cell line. JoVE (J. Vis. Exp.) 2012, 70, e4054. [CrossRef] [PubMed]

23. Jacobson, M.P.; Pincus, D.L.; Rapp, C.S.; Day, T.J.; Honig, B.; Shaw, D.E.; Friesner, R.A. A hierarchical approach to all-atom protein loop prediction. Proteins Struct. Funct. Bioinform. 2004, 55, 351-367. [CrossRef] [PubMed]

24. Jacobson, M.P.; Friesner, R.A.; Xiang, Z.; Honig, B. On the role of the crystal environment in determining protein side-chain conformations. J. Mol. Biol. 2002, 320, 597-608. [CrossRef]

25. Release, S. 2: Maestro; Version 11.8; Schrödinger, LLC.: New York, NY, USA, 2018.

26. Le Guilloux, V.; Schmidtke, P.; Tuffery, P. Fpocket: An open source platform for ligand pocket detection. BMC Bioinform. 2009, 10, 168. [CrossRef]

27. Friesner, R.A.; Murphy, R.B.; Repasky, M.P.; Frye, L.L.; Greenwood, J.R.; Halgren, T.A.; Sanschagrin, P.C.; Mainz, D.T. Extra precision glide: Docking and scoring incorporating a model of hydrophobic enclosure for protein ligand complexes. J. Med. Chem. 2006, 49, 6177-6196. [CrossRef]

28. Halgren, T.A.; Murphy, R.B.; Friesner, R.A.; Beard, H.S.; Frye, L.L.; Pollard, W.T.; Banks, J.L. Glide: A new approach for rapid, accurate docking and scoring. 2. Enrichment factors in database screening. J. Med. Chem. 2004, 47, 1750-1759. [CrossRef]

29. Friesner, R.A.; Banks, J.L.; Murphy, R.B.; Halgren, T.A.; Klicic, J.J.; Mainz, D.T.; Repasky, M.P.; Knoll, E.H.; Shelley, M.; Perry, J.K. Glide: A new approach for rapid, accurate docking and scoring. 1. Method and assessment of docking accuracy. J. Med. Chem. 2004, 47, 1739-1749. [CrossRef] [PubMed]

30. Release, S. 2: Glide; Schrödinger, LLC.: New York, NY, USA, 2018.

31. Bowers, K.J.; Chow, D.E.; Xu, H.; Dror, R.O.; Eastwood, M.P.; Gregersen, B.A.; Klepeis, J.L.; Kolossvary, I.; Moraes, M.A.; Sacerdoti, F.D. Scalable algorithms for molecular dynamics simulations on commodity clusters. In Proceedings of the SC'06: 2006 ACM/IEEE Conference on Supercomputing, New York, NY, USA, 11-17 November 2006; p. 43.

32. Shaw Research. Schrödinger Release 2019-2: Desmond Molecular Dynamics System; Shaw Research: New York, NY, USA, 2019.

33. Schrödinger. Desmond Interoperability Tools; Schrödinger: New York, NY, USA, 2019.

34. Skyner, R.; McDonagh, J.; Groom, C.; Van Mourik, T.; Mitchell, J. A review of methods for the calculation of solution free energies and the modelling of systems in solution. Phys. Chem. Chem. Phys. 2015, 17, 6174-6191. [CrossRef]

35. Maier, J.A.; Martinez, C.; Kasavajhala, K.; Wickstrom, L.; Hauser, K.E.; Simmerling, C. ff14SB: Improving the accuracy of protein side chain and backbone parameters from ff99SB. J. Chem. Theory Comput. 2015, 11, 3696-3713. [CrossRef] [PubMed] 
36. Vinter, J.G. Extended electron distributions applied to the molecular mechanics of some intermolecular interactions. J. Comput. Aided Mol. Des. 1994, 8, 653-668. [CrossRef] [PubMed]

37. Skylaris, C.-K.; Haynes, P.D.; Mostofi, A.A.; Payne, M.C. Introducing ONETEP: Linear-scaling density functional simulations on parallel computers. J. Chem. Phys. 2005, 122, 084119. [CrossRef] [PubMed]

38. Woods, C.J.; Malaisree, M.; Hannongbua, S.; Mulholland, A.J. A water-swap reaction coordinate for the calculation of absolute protein-ligand binding free energies. J. Chem. Phys. 2011, 134, 02B611. [CrossRef] [PubMed]

39. Woods, C.J.; Malaisree, M.; Michel, J.; Long, B.; McIntosh-Smith, S.; Mulholland, A.J. Rapid decomposition and visualisation of protein-ligand binding free energies by residue and by water. Faraday Discuss. 2014, 169, 477-499. [CrossRef] [PubMed] 